\title{
Olhares epistemológicos na prática pedagógica de professores de Química
}

\author{
Andreza Estéfane Silveira Gonçalves*, Marcel Thiago Damasceno Ribeiro**
}

\section{Resumo}

Este artigo se trata de um recorte de uma pesquisa de mestrado realizada com professores supervisores do Programa Institucional de Bolsa de Iniciação à Docência (PIBID) e Residência Pedagógica (PRP) do curso de Licenciatura em Química de uma Universidade pública no Estado de Mato Grosso no ano de 2019. Assim, a questão norteadora se pautou nos seguintes termos: Como se expressam as concepções de Ciência e modelos didáticos subjacentes às práticas pedagógicas de professores de Química em atuação na Educação Básica? Neste recorte se busca contextualizar as relações entre sujeito-objeto e a construção do conhecimento científico ao longo do tempo, chamando para a importância de professores conhecerem sobre as bases epistemológicas, que dão sustentação ao trabalho pedagógico científico. Ainda na perspectiva do professor, que analisa sua prática, se traz a relevância da Educação científica na sociedade e a importância de compreender a mesma. A metodologia se fundamenta na contribuição da pesquisa qualitativa, tendo como abordagem o estudo de caso, e se buscou por meio de questionários, contendo questões abertas, e entrevista semiestruturada, verificar possíveis necessidades formativas quanto às concepções de Ciência expressas pelos professores com base nas sete visões deformadas presentes na literatura. O método de análise e a construção dos textos de pesquisa se desenvolveram por meio da análise textual discursiva (ATD). Os resultados indicam uma necessidade dos professores refletirem sobre a Ciência que estão a ensinar, de forma a garantir um ensino integrador e mais significativo dos conceitos científicos. As reflexões deste levantamento contribuíram para a construção de um produto educacional em formato de fascículo com a intenção de subsidiar a formação continuada para professores em atuação, em busca de auxiliar em suas possíveis necessidades formativas no Ensino de Ciências.

Palavras-chave: Educação em Ciências; Epistemologia; Ensino de Ciências; Formação de professores.

\footnotetext{
Mestra em Ensino de Ciências Naturais pelo Programa de Pós-Graduação em Ensino de Ciências Naturais da Universidade Federal de Mato Grosso (PPGECN/UFMT). Professora da Educação Básica em Mato Grosso (SEDUC/MT). Brasil. E-mail: andreza.link@yahoo.com.br

* Pós-doutorando em Educação em Ciências e Matemática pelo Programa de Pós-Graduação em Educação em Ciências e Matemática da Universidade Federal de Goiás (PPGECM/UFG). Doutor em Educação em Ciências e Matemática pelo Programa de Pós-Graduação em Educação em Ciências e Matemática da Universidade Federal de Mato Grosso (UFMT/REAMEC). Professor Adjunto III da Área de Ensino de Química do Departamento de Química da UFMT, e dos Programas de Pós-Graduação em Educação (PPGE/UFMT), Pós-Graduação em Ensino de Ciências Naturais (PPGECN/UFMT), Campus Cuiabá, Brasil. E-mail: marceldamascenoribeiro@gmail.com
}

Recebido em: 26/10/2019 - Aceito em: 08/01/2020

https://doi.org/10.5335/rbecm.v3i1.10128

http://creativecommons.org/licenses/by-nc-nd/4.0 


\section{Introdução}

Este artigo faz parte de um recorte de dissertação de mestrado desenvolvido no Programa de Pós-Graduação em Ensino de Ciências Naturais, mestrado profissional, da Universidade Federal de Mato Grosso (UFMT), na linha de pesquisa de Formação de Professores para o Ensino de Ciências Naturais, intitulada: Epistemologia e Ensino de Ciências: uma proposta de Formação para Professores de Química e Ciências Naturais, que teve o seguinte problema de pesquisa: como se expressam as concepções de Ciência e modelos didáticos subjacentes às práticas pedagógicas de professores de Química em atuação na Educação Básica?¹.

Nesta perspectiva, apresenta-se uma leitura dos conhecimentos inerentes à formação de professores para ensinar Ciência sob a ótica da tomada de consciência, no sentido de trazer para a superfície as visões deformadas em relação ao Ensino de Ciências, para que se possa garantir um ensino integrador e mais significativo dos conceitos científicos.

Desta forma, reflete-se sobre a importância de uma Educação Científica permeada de criticidade, procurando se ausentar sempre do discurso dogmático e distorcido sobre a imagem da Ciência em que, muitas vezes, se encontra inserida dentro de um movimento de disputa entre elite e resto da sociedade. Trabalha-se na concepção de que tal visão elitista deve ser superada, rumo à garantia de um ensino integrador, em que seja possível o alcance significativo dos conceitos científicos.

Com isso, o intuito da realização da pesquisa de mestrado girou em torno de compreender as concepções de Ciência expressas pelos professores sujeitos da pesquisa e propor um produto educacional, no formato de um fascículo ${ }^{2}$, com objetivo de impulsionar uma formação continuada, que minimize as necessidades formativas frente a um ensino epistemológico de Ciência.

Assim, o objetivo deste trabalho de pesquisa é apresentar uma leitura no sentido de identificar as possíveis necessidades formativas em relação ao conceito de Ciência com base nas sete visões deformadas de Ciência, expressas por Cachapuz et al. (2005), e com base nessas, refletir sobre o Ensino de Ciências. 


\section{ofício da epistemologia na composição da didática das ciências e na formação de professores}

Ao se pensar nos aspectos que perfazem o papel do profissional docente é imperioso levar em consideração que inexiste professor de Ciências sem uma epistemologia que dê sustentação a seu fazer pedagógico. Deste modo, um professor pesquisador de sua prática necessita encarar os horizontes da formação epistemológica e interpretála à luz do contexto social no qual se insere.

Dentro desse quadro de referências se tem a educação científica, que surge como componente indispensável para o desenvolvimento social e pessoal de uma sociedade, porém a cada ano que passa se observa o insucesso popularizado e a renúncia progressiva dos estudantes em compreender as Ciências e se interessar por seguir carreira. E se demonstra que tais divergências, na natureza das Ciências, são decorrentes de como os estudantes concebem a visão de Ciência; e uma maneira de reverter esse quadro é transformar a concepção de Ciência que os professores têm, pois visões incoerentes de como se compõe a evolução da Ciência, ao longo dos anos, pode compor um obstáculo na aprendizagem (CACHAPUZ et al., 2005).

O fato do ensino científico, desde o Universitário, ter se democratizado como aplicação de um Método Científico satisfatoriamente preciso, é o que causa discrepância, e evidência para a inadequação nas concepções epistemológicas acarretando, segundo Ibidem et al: "um dos principais obstáculos aos movimentos de renovação da Educação Científica" (2005, p. 39). Assim, para mudar a realidade das aulas científicas é preciso formar o professor de Ciências com preceitos epistemológicos, para garantir que esse tenha uma melhor compreensão da atividade científica e da epistemologia atual, pois ainda que esse profissional possua concepções válidas sobre Ciência, não é garantia que atue de acordo com tais concepções (Ibidem et al, 2005).

O método é um processo investigativo no qual o fundamento desse percurso é alcançar conhecimento sobre o objeto, e a forma como isso irá ocorrer é definida pelo tipo do objeto a ser investigado. Tendo dito isso, pode-se agora compreender melhor como ocorre o processo epistemológico ao longo do tempo. Gamboa (2014) aborda, em suas reflexões, que: "o discurso epistemológico encontra na filosofia seus princípios e na ciência seu objeto” (p. 29), tal que a epistemologia pode ser vista como a congruência entre a Filosofia e Ciência, dando enfoque em compreender a trajetória do conhecimento, e podendo ser também definida como teoria do conhe- 
cimento ou saber crítico, porém essa não é objeto metodológico, nem uma teoria global dos saberes, a Ciência é tida como objeto e, ao mesmo tempo, percurso do processo (GAMBOA, 2014).

O espiral epistemológico é sempre interpretado à luz de um contexto dos pontos de vista: histórico, religioso, econômico e político, uns dos seus papéis é compreender o processo gnosiológico científico com intuito de conceber os saberes científicos de forma reflexiva e distante da ideia de conhecimento acabado. Essa espiral toma para si a análise de problemas e soluções de cunho filosófico se atentando aos métodos e a realidade da investigação crítica. Outra utilidade é ser capaz de reconhecer se a Ciência é autêntica ou falsa. Esse é o papel da epistemologia, trazer à tona os pressupostos filosóficos que subjazem os métodos ou resultados apresentados no processo de investigação. Esclarecer, regular, recompor conceitos e teorias científicas, que ajudem a explicar e solucionar divergências na Ciência (TESSER, 1994).

No decorrer desta seção se busca englobar os principais pressupostos epistemológicos ao longo do desenvolvimento científico até chegar às novas concepções filosóficas, nas quais a Ciência nos dias atuais se encontra.

\section{Articulando Relações entre Sujeito-objeto do Conhecimento}

Ao se analisar os modelos epistemológicos de formação se faz necessário recorrer para a importância de se relacionar sob a ótica de conjuntura temporal, não apenas abordando a variável tempo como uma dimensão inerte do processo para se referir a uma determinada época, mas sim como uma perspectiva que relaciona causa e efeito no espaço do processo. Antes de se abordar as formas de conhecimento é importante compreender que esse se faz sob a ótica do sujeito e do objeto e a relação entre esses deve ser vista, sob uma perspectiva temporal, que seja em consideração de uma cultura, de um código e de valores, assim, não existe neutralidade ao se analisar o conhecimento.

Cabe salientar sobre a importância de compreender os modelos epistemológicos, pois os mesmos influenciam nos modelos pedagógicos que acompanham as práticas dos professores de forma muitas vezes inconsciente. Por mais que não se esteja imerso em leituras sobre o assunto e nem se tenha tido formação com base filosófica é importante conhecer como ocorreu a história da Ciência, a qual se ensina, pois por mais que se tenha formação em uma área, cuja Ciência tenha sido matematizada e 
seja essa ensinada aos alunos, existe uma filosofia por trás que dá base e justifica todo o aporte teórico com o qual se ensina e se acredita.

O primeiro modelo parte do pressuposto epistemológico empirista, conhecido também como modelo realista, e associado a um processo de ensino e aprendizagem, o mesmo fica conhecido como pedagogia diretiva, segundo essa visão epistemológica, o sujeito se encontra em detrimento do objeto, ou seja, o objeto é determinístico (GAMBOA, 2014).

O empirismo constitui uma corrente filosófica que se pauta na forma de conhecimento baseado na experiência, através de dados coletados dessa. A utilização dos sentidos tem caráter fundamental, de forma que todo conhecimento é proveniente das percepções que o ser tem do real, das coisas advindas do mundo externo para a pessoa, assim, o empirismo nega toda a concepção de que existe forma de conhecimento que seja decorrente do inatismo ${ }^{3}$ (MARCONDES, 2011).

O positivismo de Auguste Comte (1798-1857) teve forte influência do empirismo, sendo esses colocados, em muitos textos, como a mesma coisa, porém este se constituiu da síntese do empirismo, e do racionalismo de Descartes. O empirismo juntamente com o racionalismo são os paradigmas alicerçadores da Filosofia e da Ciência Moderna promovida a partir do século XVI. A expressão modernidade é acompanhada de novidade, de ruptura da tradição, e esse conceito de Ciência Moderna ocorre com a mudança de paradigma geocêntrico para heliocêntrico, a chamada Revolução Científica, que teve como um dos pontos de partida a obra: Sobre a revolução dos orbes celestes, em 1543, de Nicolau Copérnico, que legitima por meio da matemática o sistema que coloca o Sol como centro, e a Terra apenas como mais um astro, rompendo com a concepção escolástica de inspiração Aristotélica formulada por Ptolomeu no século II de que a Terra era o centro do Universo.

Essa mudança de paradigma marcou o início da era da modernidade, que mudou a forma do homem pensar e até mesmo se enxergar, em vigor por mais de vinte séculos, como cita Marcondes (2011): “esse novo modelo de cosmo abala profundamente as crenças tradicionais ao homem da época, não só quanto à ordem do universo, mas também quanto a seu lugar centram nessa ordem" (p. 254). Assim, o conflito gerado na transição desses modelos de Ciência colocou em cheque, no século XVI, a própria concepção de Ciência, pois se durante vinte séculos se viveu sob a perspectiva de uma teoria falsa, não existiria garantia nenhuma de que a nova apresentaria diretrizes de verdade no meio do mar de incertezas (MARCONDES, 2011). 
Dessa forma, Descartes se propõe definir uma nova ordem de conhecimentos, que definiriam o novo mundo e demonstrariam a possibilidade de ocorrência de erros, por meio do uso correto da razão, através da construção de quatro regras e princípios, que até hoje são utilizadas. Tais regras são de fácil compreensão e têm inspiração na geometria, e seu fator chave é que essas devem ser rigorosamente seguidas e bem observadas. Marcondes (2011) explana tais regras como sendo:

A primeira é a da regra da evidência "jamais aceitar uma coisa como verdadeira que
eu não soubesse evidentemente como tal"; a segunda, a regra da análise: "dividir cada
uma das dificuldades que eu examinasse em tantas partes quantas possíveis e quan-
tas necessárias para melhor resolvê-las"; a terceira, a regra da síntese: "conduzir por
ordem meus pensamentos, a começar pelos objetos mais simples e mais fáceis de se-
rem conhecidos, para galgar, pouco a pouco, como que por graus, até o conhecimento
dos mais complexos" e, finalmente, a quarta: "fazer em toda parte enumerações tão
complexas e revisões tão gerais que eu tivesse a certeza de nada ter omitido (p. 162).

Vários outros filósofos, inspirados nessa base de conhecimentos definida por Descartes, desenvolveram novas teorias em um híbrido do método cartesiano, como Comte (1973), que em sua busca de ordem como guia de progresso e sobrevivência social, analisando a realidade a partir dos fatos, e Durkheim (1973), que através de As regras do método Sociológico, estuda os fenômenos sociais como sendo coisas dotadas de existência própria, passíveis de serem generalizadas sob uma interpretação externalista, os sujeitos em sociedade são determinados com o meio no qual interagem, porém o papel do sujeito na sociedade não é considerado, esse é determinado, não gera, não cria. O pesquisador que adota a postura positivista se utilizará do método da objetividade, o objeto a ser estudado, seja esse qual for, será tratado como uma coisa apartada de um contexto, com isso será quantificado e os resultados serão apresentados pelo pesquisador de forma neutra, não abrindo precedentes para possíveis opiniões internas (CAVALCANTI, 2014).

Apresenta-se agora o olhar epistemológico internalista, que chama para 0 diálogo aquele que está incluído, vivenciando o fenômeno. Como já explanado no início deste tópico, quando se quer compreender o processo histórico crítico da construção do conhecimento se deve levar em consideração a perspectiva temporal. A formação da consciência de um indivíduo, a maneira como esse enxerga o mundo está diretamente associada aos encadeamentos históricos e culturais, então, a possibilidade do ser conhecer e representar o real ocorre do contato com o fenômeno (MARCONDES, 2011). 
A fenomenologia, como é denominada a corrente filosófica que aborda tais concepções, surge na primeira metade do século XX como uma crítica ao Positivismo. Teve como idealizador Husserl, que utilizou como base o termo, inicialmente utilizado por Lambert, ao caracterizar a Ciência das aparências. A fenomenologia de Husserl não tem como objetivo fundamentar o conhecimento científico, assim como foi necessário no início da modernidade, mas sim buscar significado nas coisas que expõe para a sociedade (MARCONDES, 2011).

Para ter entendimento de um fenômeno se deve percorrer uma trilha, e esse processo de buscar um caminho para chegar ao sentido das coisas é típico da história da filosofia do Ocidente. Ao buscar esse sentido, Husserl faz uso de duas etapas, sendo a primeira dessas a redução eidética, que consiste em capturar o sentido das coisas, ou seja, a essência. A forma como os fatos surgem na consciência pessoal é chamada de $e^{i d o{ }^{4}}$, assim, a compreensão de um fenômeno pelo sujeito ocorre pela vivência, a relação do eu com o fato presente no aqui e no agora. Um fenômeno é a aparência que se tem das coisas (BELLO, 2006).

Compreender o sentido das coisas é algo de suma importância para o ser humano, porém nem todas as coisas têm compreensão instantânea, o interessante é compreender o sentido das coisas, deixando de lado o que não é sentido, uma máxima utilizada é: "não interessa o fato de existir, mas o sentido desse fato" (BELLO, 2006, p. 23). A fenomenologia é a Ciência das essências, interessa-se em analisar e descrever a essência como essa é, então, o sujeito primeiramente percebe e busca sentido para o fenômeno, seja esse uma coisa física ou não física, o método filosófico fenomenológico ao buscar sentido não considerará tudo aquilo que não seja o sentido das coisas (BELLO, 2006).

A segunda etapa da busca de conhecimento é a redução transcendental, que busca compreender o sujeito que procura o sentido nas coisas. Husserl faz uso de duas terminologias, noesis é o ato de possuir consciência e noema que são as coisas que chegam à consciência de alguém, através dos sentidos como tato e visão se têm as sensações fundamentais, assim são captados por meio dos sentidos e a pessoa se dá conta de algo pela consciência, "o ser humano tem a capacidade de ter consciência de ter realizado esses atos, enquanto ele está vivendo esses atos, sabe que os está realizando" (BELLO, 2006, p. 31).

A experiência que o sujeito tem com o fenômeno é o principal fator do método fenomenológico, porém pensando no percurso metodológico cabe frisar que o uso 
dessa experiência não ocorre de forma exclusivamente individual de cada pesquisador, mas sim em um conjunto de concepções de outros pesquisadores, enquanto sujeitos individuais também esta é a principal diferença da Fenomenologia e do Positivismo. A fenomenologia dá voz ao pesquisador, esse não é mais um ser neutro, que apenas quantifica e descreve o objeto como esse é, mas sim um ser ativo, que faz uso de suas interpretações sobre o fenômeno através de suas perspectivas, juntamente com outros sujeitos, todos apreendendo a essência e em conjunto podendo generalizá-las (CAVALCANTI, 2014).

O olhar multirreferencial nasce do pensamento contemporâneo como resposta ao conhecimento formulado na modernidade por Descartes, que expõe que, ao longo dos anos, as partes de um todo de um problema foram cada vez mais divididas para equacionar a solução, isso ocasionou um abismo entre as relações sujeito-objeto, exterior-interior. A complexidade se insere no paradoxo sociológico, nasce para trazer entendimento e romper com todo simplismo da supremacia preponderante da dita verdade universal.

Um dos principais autores a abordar o pensamento complexo é Edgar Morin, que apresenta uma visão holística do conhecimento, fazendo uso da dialética para compreender a relação sujeito-objeto, "a complexidade está, pois, ligada a certa mistura de ordem e de desordem, mistura intima" (MORIN, 2006 p. 35). Assim, a complexidade não quer apenas juntar o sujeito e objeto, mas trazer uma nova postura para a compreensão. Para Morin (2006), a complexidade se relaciona com a incerteza, porém dentro de sistemas organizados que não se separam em uma mistura íntima, sendo assim:

\footnotetext{
Ora, o problema teórico da complexidade é o de possibilidade de entrar nas caixas-pretas. É considerar a complexidade organizacional e a complexidade lógica. Aqui, a dificuldade não está apenas na renovação da concepção do objeto, está na reversão das perspectivas epistemológicas do sujeito, isto é, do observador científico: era próprio da ciência, até o momento, eliminar a imprecisão, a ambiguidade, a contradição (MORIN, 2006, p. 35).
}

Portanto, o pensamento complexo lança mão de toda unidimensionalidade, ao analisar a realidade social e integra a multidimensionalidade, que são ausentes no paradigma simplificador. A complexidade não estuda um sistema como sendo isolado, e enxerga, por exemplo, que a sociedade tem uma dinâmica que tende a estabilidade e a auto-organização (CAVALCANTI, 2014). 
Existem três princípios que dão sustentação ao pensamento complexo, sendo: o princípio hologramático, princípio da organização recursiva e princípio dialógico. O primeiro desses faz referência à figura de um holograma, que apresenta as informações fidedignas de um objeto bidimensional de forma tridimensional. Assim, esse princípio permite compreender as relações entre partes e o todo, sendo que as partes de algo compõem o todo, assim como o todo apresenta as partes de algo, "a complexidade rejeita ao mesmo tempo o reducionismo de querer compreender o todo partindo só das partes e o holismo que quer compreender o todo negligenciando as partes" (Ibidem, 2014, p. 996).

$\mathrm{O}$ segundo princípio diz respeito à organização recursiva, que transpassa 0 pensamento linear, enxergando a complexidade não como apenas a junção de fenômenos empíricos, mas levando em consideração os limites de fronteiras imprevisíveis, que não permitem separar causa e efeito de um fenômeno. Por último, o princípio dialógico em que se pode "estabelecer relação entre aspectos antagônicos e ao mesmo tempo complementares, sem negar ou reduzir a complexidade desta relação" (Ibidem, 2014, p. 996).

A complexidade como método relacional não faz distinção entre sujeito e objeto e corre atrás da busca de certezas, pelo contrário, seu olhar está voltado para a ação simultânea entre o sujeito e o objeto, assim como o objeto e o sujeito, considerando as incertezas do acaso no processo e busca explicações entre os diversos saberes na ótica transdisciplinar, não existindo distinção entre quali e quantitativo, Ciências Humanas e Naturais ou biológico e cultural (Ibidem, 2014).

Por fim, ao se analisarem as principais relações epistemológicas, é adequado enfatizar que não existe epistemologia certa ou errada, são várias possibilidades de se ler a realidade, e a epistemologia é a forma metodológica que propicia explicação para as diversas formas de produção de conhecimento científico existentes. Uma metodologia está sempre vinculada a uma teoria e existe uma epistemologia que por trás proporciona subsídio para a mesma, então ao se fazer uma leitura de mundo se está carregando uma crença, que permite que a pessoa seja neutra ou ativa no processo de transformação da realidade, e enquanto agente ativo no processo educativo se deve organizar as compreensões, esclarecer e se posicionar epistemologicamente de forma consciente. 


\section{A relevância da educação científica na sociedade}

a compreensão da alfabetização científica propagada nos dias atuais ocorreu ao final dos anos 1950, porém somente na década de 1990 a mesma adquiriu o status que possui atualmente, diante das exigências por contribuições de pesquisas e de inovações neste campo ${ }^{5}$, através do Journal of Research in Science Teaching ${ }^{6}$ (CACHAPUZ et al., 2005).

A popularidade da Alfabetização Científica (AC) fez ecoar muitas opiniões advindas dos vários sujeitos que a compõe, por meio de um amplo movimento educativo, que se identifica e participa por trás desta metáfora educacional. Cachapuz et al. (2005) vem trazer contribuições sobre o que se entende por tal expressão, que possui um caráter dúbio, fazendo com que tenham várias interpretações, dificultando assim que se chegue a um consenso de orientação em seu emprego efetivo.

O referido autor se apropria do conceito de metáfora para se referir à Alfabetização Científica (AC), se distanciando do simplismo que essa terminologia pode ter se analisada pelo seu significado literal de aprender, especificamente, o vocabulário científico. Cachapuz, et al, (2005) se apoia em dois olhares para tecer uma análise crítica à Alfabetização Científica $(\mathrm{AC})$, envolvendo a ótica da necessidade ou do mito $^{7}$, refletindo se esta é realmente útil na sociedade.

De um ponto de vista, a Alfabetização Científica (AC) é abordada de forma multidimensional, que permite que o estudante tenha compreensões da Ciência, que envolvam aspectos históricos e tecnológicos sobre o papel que a mesma possui na vida individual e na sociedade como um todo, indo além dos moldes tradicionais de transmissão do método científico, podendo aproximar o cidadão das tomadas de decisões na sociedade. Por outro lado, existe uma corrente que possui uma opinião contrária a respeito da importância da Alfabetização Científica (AC) para todos, e existem duas discussões, denominadas de tese pragmática e tese democrática, baseadas em ideias preconcebidas. Nessa perspectiva, Cachapuz et al. (2005) aborda que:

A primeira, que denomina tese pragmática, considera que, dado que as sociedades estão cada vez mais influenciadas pelas ideias e produtos de ciência e, sobretudo, de tecnologia, os futuros cidadãos desenvolver-se-ão melhor se adquirirem uma base de conhecimentos científicos. A segunda, ou tese democrática, supõe que a alfabetização científica permite aos cidadãos participar nas decisões que as sociedades devem adoptar em torno a problemas sociocientíficos e sócio-tecnológicos cada vez mais complexos (CACHAPUZ et al., 2005, p. 23). 
Ambas as teses trazem argumentos importantes para a promoção da Alfabetização Científica (AC), porém podem ser analisadas por uma ótica cética. A tese pragmática não considera que, atualmente, os cidadãos não podem se desenvolver de forma independente sem dominar as operações matemáticas básicas, juntamente com a leitura e a escrita, mas conseguem realizar suas atividades diárias sem o conhecimento da Ciência. Um olhar pessimista sobre a tese democrática se encontra em pensar que nunca será possível educar cientificamente uma sociedade com os conhecimentos que são ensinados em âmbito escolar, que para garantir que os cidadãos cheguem ao nível necessário para compreender questões relativas às Ciências, sendo necessário que se tenha uma base de conhecimento superior à somatória de todos os conhecimentos, que são atualmente ensinados na formação de futuros cientistas (CACHAPUZ et al., 2005).

Pautada nas interpretações, a Alfabetização Científica (AC) é vista como um mito e que seu desenvolvimento só acarreta em gastos de recursos desnecessariamente. Cachapuz et al. (2005) não concordam com tal postura pessimista, porém acham justo se distanciar do simplismo que a Alfabetização Científica (AC) seja algo óbvio, para isso vêm refletir sobre as contribuições que a Alfabetização Científica (AC) tem na formação de cidadãos, e analisam pela perspectiva de que o conhecimento científico vai muito além do que formar especialistas, e que a participação efetiva de cidadãos na tomada de decisões é possível se somada a um conhecimento mínimo, que relacione questões globais, éticas e morais, pois o domínio efetivo de conceitos científicos não garante a tomada de decisões corretas por parte de quem os têm.

A sociedade, em geral, pode participar em questões que envolvam problemas no âmbito mais amplo, analisando os entraves em médio e em longo prazo, porém isso só será possível se o indivíduo possuir um conhecimento mínimo do assunto atrelado com a questão estudada. Como exemplo disso se encontra o caso dos alimentos transgênicos, que possui grande repercussão na mídia em função de debates intensos por parte de sociedade a respeito dos efeitos nocivos à saúde. Cachapuz et $a l$. (2005) contribuem no importante fato de que:

Devemos insistir em que esta participação dos cidadãos na tomada de decisões, que se traduz, em geral, em evitar a aplicação apressada de inovações das que se desconhecem as consequências a médio e longo prazo, não supõe nenhum impedimento ao desenvolvimento da investigação, nem para a introdução de inovações para as que existam razoáveis garantias de segurança (CACHAPUZ et al., 2005, p. 28). 
Pode-se, com base em tais contribuições, estabelecer a reflexão de que a Ciência se encontra em uma disputa entre elite e resto da sociedade, entre conhecimento para o bem e para o mal, e existe um amplo movimento, e uma série de forças de resistências que caminham para um apartheid de conhecimentos próprios ou não para determinadas classes, enquanto essa deveria ser vista sob a ótica de libertação, porém tal dogmatismo em que a Ciência se encontra inserida é fruto de longos anos de um ensino acrítico, que corrobora com o discurso de que a Ciência é feita por uma elite e é inacessível ao resto da população. Essa maneira de abordar a Ciência contribui para uma imagem distorcida, acarretando na falta de interesse por muitos em função de tal visão deformada da Ciência. Tal visão elitista deve ser superada para que se possa garantir um ensino integrador, que torne possível uma aquisição significativa dos conceitos científicos (CACHAPUZ et al., 2005).

Dessa forma, o próximo tópico abordará as sete necessidades formativas expressas por Cachapuz et al. (2005), e a questão da necessidade de superar tal visão deformada que a Ciência possui em prol de um ensino de Ciências mais efetivo.

\section{Necessária renovação no Ensino de Ciências: as sete visões deformadas de Ciência}

Pode-se pensar que os professores de Física, de Química e de Biologia, tendo o conhecimento das transformações que são pertinentes às Ciências da Natureza, estariam aptos a ensinar com clareza como ocorreu o processo de construção do conhecimento científico, porém numerosos estudos têm apresentado que esse pensamento está longe de ser verdade. O próprio ensino universitário, que deveria ensinar o processo de construção do conhecimento até chegar à linguagem universal presente atualmente, transmite uma visão empírico-indutivista da Ciência, e essa visão tem acompanhado a prática desses docentes que se incorporam dessas concepções ainda quando estudantes, pois na maioria das vezes não receberam um ensino investigativo e veem a Ciência como metódica e única, acarretando no Ensino Tradicional, que limita o professor de colocar em prática sua criatividade e a versatilidade de se adaptar às diferentes realidades vividas na função docente.

Partindo de reflexões desse gênero que surgiu a necessidade de investigar as concepções epistemológicas errôneas que acompanham a prática tradicional. Dessa forma, na década de 1980, com o movimento das concepções alternativas, que veio 
questionar o ensino de aprendizagem por transmissão de conteúdos elaborados anteriormente, surgiu a Didática das Ciências com a intenção principal de formar um novo tipo de profissional, desconstituído das visões simplistas sobre o ensino de Ciências, pautado em que a atividade docente era fácil, bastando apenas conhecer o conteúdo. Esse novo campo de investigação contribuiu para estimular as reflexões acerca do ensino e aprendizagem, pautadas no construtivismo, e além de tratar das concepções prévias dos alunos, o professor passou a ter o compromisso não apenas de conhecer o conteúdo, mas sim de assumir um senso didático que se refere às concepções científicas (CACHAPUZ et al., 2005).

A necessidade de vir à tona esse novo campo de conhecimento, culminando em mudanças decisivas de concepções tradicionais, seriamente habituadas, faz parte de um movimento que viu a necessidade de sair da inércia de impregnação ambiental, que acompanhou e acompanha muitos docentes. Além de que a forma de ensino tradicional impregnada de visões empobrecidas e distorcidas acarreta em falta de interesse e, muitas vezes, rejeição por parte dos estudantes, criando assim obstáculos de aprendizagem (CACHAPUZ et al., 2005).

Dessa forma, as complicações começaram a se aglomerar, e a necessidades de novas teorias para resolver os problemas começaram a surgir. Então, houve a necessidade de recorrer às contribuições teóricas de áreas como Sociologia, Psicologia, Antropologia, entre outros. Nesse sentindo, Cachapuz e colaboradores corroboram que:

Considerar a Didática das Ciências uma simples aplicação prática das Ciências da Educação, pode fazer com que ignoremos a importância da Epistemologia da Ciência para uma melhor aprendizagem das Ciências (...). Trata-se de fazer um maior aproveitamento do que podemos conseguir da Psicologia da Educação, sem cair nas, claramente ineficazes, aplicações mecânicas (2005, p. 187).

Sendo assim, o que caracteriza esse novo campo de pesquisa tem sido sinalizado pela singularidade do conhecimento científico, que existe na origem dos obstáculos de ensino e aprendizagem examinados, acarretando em estudos sobre mecanismos didáticos mais satisfatórios ao ensino daquele saber, e apurações sobre métodos que sejam mais bem capazes de necessárias reconstruções conceituais e mudanças didáticas para o ensino daquele que se encontra em situações escolares estabelecidas. Isso exprime que o ensino de Ciências/Química acarreta na mudança de conhecimento científico/químico em escolar, concebendo a primordialidade de constituição de uma 
nova zona de estudos e análise de questões, que compõem a essência das discussões sobre o como, o quê e o porquê ensinar Ciências/Química (SCHNETZLER, 2002).

Antes de abordar as possíveis visões deformadas existentes na Ciência, cabe acentuar que o papel desta pesquisa não é demonstrar que existe uma forma correta e exclusiva de concebê-la, pois ao se falar de deformações se passa a impressão de que a Ciência não se encontra dentro de um padrão imutável estabelecido universalmente. Devem ser afastadas as compreensões dessa ordem. O objetivo aqui é fazer uma investigação crítica das deformações existentes na Ciência e que, muitas vezes, se encontram presentes em práticas docentes, de forma implícita ou explícita, e são ensinadas sem que o docente reflita sobre sua fidedignidade (CACHAPUZ et al., 2005).

A seguir são apresentados os resultados de pesquisas de Cachapuz et al. (2005), por meio da sistematização de deformações apresentadas por vários professores sobre concepções de Ciências. As visões presentes na literatura se apresentam conectadas e marcadas por aspectos empiristas como fruto de uma longa formação ambiental, que ainda não superou a marca do Positivismo (PRAIA; CACHAPUZ, GIL-PÉREZ, 2002). As concepções deformadas de Ciência descritas por esses autores são destacadas como: 1) uma visão descontextualizada; 2) uma concepção individualista e elitista; 3) uma concepção empiro-indutivista e ateórica; 4) uma visão rígida, algorítmica e infalível; 5) uma visão aproblemática e ahistórica; 6) uma visão exclusivamente analítica e 7) uma visão cumulativa, de crescimento linear.

A primeira deformação, expressa por Cachapuz et al. (2005), aborda a ocorrência de uma visão descontextualizada de Ciência, como o nome já indica, a Ciência é vista como neutra e sem um contexto relacionado com a sociedade e a atividade tecnológica. As relações Ciência-Tecnologia-Sociedade (CTS) são ignoradas. Essa deformação é ocasionada pela falta de esclarecimento da conexão entre tecnologia e Ciência, na qual de fato existe um pensamento arraigado de que os avanços tecnológicos são decorrentes das contribuições da Ciência. Existe a cultura de que os menos favorecidos fazem cursos de nível secundário, como cursos técnicos para serem mão de obra e os de condições sociais mais favorecidas ficam a cargo do trabalho intelectual. No entanto, basta analisar o desenvolvimento histórico de ambas para que se tenha a clareza de que a atividade tecnológica antecedeu a científica, como o molde que citam Cachapuz et al. (2005): "o ponto de partida da Revolução Industrial, por exemplo, foi a máquina de Newcomen, que era fundidor e ferreiro” (p. 45). 
O ponto em questão não é querer fazer uma competição de poderes entre a Ciência e a Tecnologia, mas sim demonstrar que o papel dos técnicos está em desenvolver sistemas que facilitem e atendam às necessidades humanas, mais do que em criar um arcabouço teórico de explicações subjacentes como fazem os cientistas. Essas relações deformadas, que se têm da Ciência e da Tecnologia, acarretam uma deformação também na visão de CTS presentes nos livros didáticos, sendo a relação abordada poucas vezes e de forma a demonstrar as aplicações do conhecimento científico, frisando na visão de que a Ciência é a chave do progresso, ou se segue por uma nova tendência simplista de que a Ciência e a Tecnologia são as culpadas das degradações no Planeta, ignorando que os cientistas estudam os problemas atuais enfrentados no Planeta e as possíveis soluções são estudadas por eles também. E se deve levar em consideração que nem todos os cientistas e técnicos produzem compostos que prejudicam o Planeta, isso ocorre em união com empresários, trabalhadores, economistas e políticos (CACHAPUZ et al., 2005).

A próxima concepção distorcida se denomina de: individualista e elitista, aqui a Ciência aparece como determinada por descobertas de um único cientista não levando em consideração o trabalho conjunto, o conhecimento científico é tido como esotérico ${ }^{8}$, e também ocorre um efeito pigmaleão quanto à natureza sexual da Ciência, tendo em vista que como geralmente a Ciência era produzida por homens, então culturalmente se tem um maior incentivo para o ingresso de homens na Ciência, tornando a mesma uma atividade masculina. A visão individualista pode ser expressa por imagens de homens de jaleco, isolados em laboratórios, sendo cercados por aparatos. Não se observa uma tentativa de mudança dessa realidade, em tornar a Ciência mais atingível, nem para mostrar a expor a natureza da construção humana, passível de erros (GIL PÉREZ et al, 2001).

Existe uma deformação que vai à contramão da citada, na qual a Ciência é vista como uma atividade simplória e adjacente do senso comum, não considerando que o desenvolvimento científico se inicia do questionamento do evidente, em oposição ao senso comum (CACHAPUZ et al., 2005). O olhar da tecnologia, como sendo serva da Ciência, corrobora para esta visão individual e elitista, a interação Ciência-Tecnologia acontece de forma complexa e ocorre pela integração de diferentes grupos do conhecimento e raramente se conceberá por uma pessoa exclusiva ou só por um grupo. Deve-se levar em consideração a colaboração dos técnicos nos avanços 
tecnológicos. Como afirmam Cachapuz et al. (2005, p. 44): "não se pode escapar à realidade de que a maioria dos avanços científicos estão baseados na tecnologia".

A deformação baseada em uma concepção empírico-indutivista e ateórica é a deformação mais estudada, e se pauta na observação passiva das experiências do meio físico, subsidiada por visões ateóricas centradas no método. As ideias aprioristas, que geram hipóteses que são o pilar do início de uma investigação, e as teorias já existentes na literatura que norteiam o processo não têm nenhum papel nessa visão. Como Cachapuz et al. (2005) afirmam: "a observação e a experimentação científica estão carregadas de uma competência prática prévia” (p. 47). Porém, tanto nas escolas como nas universidades, todo valor do trabalho experimental que poderia ser relacionado às ideias prévias e na compreensão da construção do conhecimento são reduzidas à montagem e ao manuseio de aparelhos quanto à replicação de roteiros. A concepção empiro-indutivista e ateórica tem como unidade o método científico e, muitas vezes, não se tem acesso real ao trabalho experimental desenvolvido, o que acarreta mais duas graves concepções deformadas, que serão abordadas adiante.

A quarta deformação propagada entre os professores é a que repercute uma visão rígida, algorítmica, infalível, contemplando a visão rígida do trabalho científico que aborda que o método deve ser seguido rigorosamente, se opõe a toda imaginação e instalação de incertezas para descobrimento de algo novo. É imperioso que se reconheça um pensamento contrário a esse, pois o processo científico deve ser permeado de tentativas e busca de novos meios para elucidar questões (CACHAPUZ et al., 2005). Um professor com uma visão empírico-indutivista passa a seus alunos uma visão endeusada do método científico, nas aulas práticas nas quais se deve seguir rigorosamente um roteiro, e se os resultados forem diferentes daquela resposta preestabelecida, o experimento é considerado como errado.

A quinta concepção de Ciência: aproblemática e ahistórica, nesta a Ciência é tida como salvacionista, existe uma visão dogmática de que a mesma é pronta e acabada, se algo é cientificamente comprovado, então não precisa ser questionado. Nessa concepção se observa a não relação com um problema, a Ciência é vista como algo fragmentado, não leva em consideração a evolução histórica da mesma. Por se observar amplamente essa deformação é comum se observar, em sala de aula, que os professores de Ciências, muitas vezes, introduzem dado conceito e não levam em consideração o problema que foi pensado na origem da construção de tal conhe- 
cimento, tal visão aproblemática pode ser encontrada também em diversos livros didáticos (GIL PÉREZ et al, 2001).

A próxima visão é a exclusivamente analítica, que vê o estudo da Ciência como dividido em parcelas e simples, não se considera a visão holística do trabalho científico, dificultando assim o tratamento interdisciplinar entre os diversos ramos da Ciência (CACHAPUZ et al., 2005).

Por último, apresenta-se a visão acumulativa, de crescimento linear, não levando em consideração as reformulações que houve durante a história da Ciência. O conhecimento científico aparece como uma acumulação linear ao longo do tempo, e não são considerados paradigmas e as diversas mudanças de concepções que ocorreram ao longo dos anos, como se a Ciência fosse fruto de história escrita por linhas retas e teorias congruentes entre si (CACHAPUZ et al., 2005).

Com base em tais visões deturpadas de Ciência serão apresentadas adiante as concepções de Ciências apontadas pelos professores participantes da pesquisa.

\section{Metodologia}

Nesta seção se descreve sobre a opção metodológica, sujeitos, objeto e caminho investigativo que a pesquisadora percorreu para uma compreensão mais ampla do estudo. Optou-se por realizar a pesquisa tendo como base as conjecturas da abordagem do estudo de caso, que é método de investigação que fornece parâmetros para que o pesquisador estude uma especificidade de um caso individual. As conjecturas desta metodologia estão em estabelecer um caso contemporâneo, que possa ser delimitado e, com isso, estudar e interpretar melhor o problema (YIN, 2001).

Sendo o estudo de caso o método que mais bem se adequa à questão de pesquisa se optou por não buscar compreender a prática pedagógica dos sujeitos no chão da escola, mas através do relato de suas concepções ao narrarem suas práticas, pressupondo que aquilo que expressam, em suas narrativas, condiz com suas práticas em sala de aula.

Em relação ao lócus da pesquisa, essa compreendeu o ambiente do curso de Licenciatura em Química do campus Cuiabá, de uma Universidade pública do Estado de Mato Grosso ${ }^{9}$, no qual se inclui o Programa de Bolsa de Iniciação à Docência (PIBID) e a Residência Pedagógica em Química (PRP) da mesma Universidade. O motivo da escolha do cenário desta pesquisa se justifica pela potencialidade que 
ambos os programas possuem na formação inicial dos licenciandos em Química. Os sujeitos desta pesquisa são sete professores que compõem os programas, sendo quatro deles participantes do PIBID e três participantes da Residência Pedagógica, que se propuseram a participar da presente pesquisa.

Entre as várias indagações que deram subsídio para elaboração desta pesquisa, um dos interesses se centra em saber dos professores participantes quais as concepções de Ciência, que dão base ao ensinar Química. Os dados foram coletados e analisados com base em um questionário, na busca de compreender a concepção de Ciência e trabalho científico, utilizando como base a obra de Cachapuz et al. (2005), bem como entrevista semiestruturada.

Para a análise do questionário e entrevista foi utilizado o aporte da Análise Textual Discursiva (ATD) com base em Moraes e Galiazzi (2011). Então, tomando como base a coleção de textos produzidos pelos professores, através dos questionários e entrevista, que ocasionou na produção de outros textos que tiveram como foco estabelecer as relações com o objeto de investigação. A intenção dessa análise não é demonstrar uma concepção de que se seja melhor ou pior, mas sim compreender as respostas dos professores às indagações realizadas para contribuir em um processo de formação, que os oportunizem a refletir sobre a Ciência que estão a ensinar.

O passo inicial da análise consistiu no processo de unitarização, ressaltando as partes que garantissem representatividade, tal processo ocorreu através de incessantes leituras do corpus para então fragmentar os textos, sucedendo então as unidades de análise. O segundo passo da análise ocorreu pelo processo de categorização, momento que se estabeleceram relações por meio de agrupamentos comuns. Para esta pesquisa se fez uso do método dedutivo de categorização, no qual as categorias surgiram antes da existência do corpus, baseadas em teorias que deram fundamentos para realização de toda a pesquisa.

\section{Concepções de ciência expressas pelos professores supervisores do pibid e da residência pedagógica}

Conduzindo pela metodologia da Análise Textual Discursiva (ATD), a primeira categoria de análise a ser investigada, tanto na escrita dos professores quanto em suas falas por meio da entrevista, se pauta em averiguar a ideia de Ciência que mais se aproximava de suas concepções. Para essa primeira questão foram 
apresentadas três alternativas fechadas entre as quais os professores deveriam escolher uma e justificar o motivo da escolha. As alternativas apresentadas foram:

a) Ciência é um conjunto organizado de conhecimento que comumente é abordado em uma disciplina.

b) Ciência é a atividade que os investigadores desenvolvem, quando buscam encontrar respostas aos problemas apresentados.

c) Ciência é o processo por meio do qual, em cada época, se procura satisfazer os interesses e as necessidades da sociedade.

Analisando as proposições, se percebe que na alternativa A, a concepção de Ciência é apresentada como sendo apenas um saber escolar, um conjunto de conhecimentos que deve ser compreendido em uma disciplina. Na alternativa B, a Ciência é apresentada como uma atividade específica, que é desenvolvida por um tipo de indivíduo para um dado fim. E na alternativa $\mathrm{C}$ são incorporadas dimensões históricas e sociais na concepção de Ciência.

Apresenta-se a seguir o quadro $1 \mathrm{com}$ as alternativas respondidas para a primeira questão e as justificativas expressas pelos professores participantes ${ }^{10}$.

Quadro 1: Respostas dos professores na questão 1

\begin{tabular}{|l|c|l|}
\hline Professores & Alternativa & \multicolumn{1}{|c|}{ Justificativa } \\
\hline Atena & B & Porque considero a Ciência dinâmica e uma atividade investigativa. \\
\hline Deméter & B & $\begin{array}{l}\text { Porque a Ciência surgiu da procura por melhorar o bem-estar, a quali- } \\
\text { dade de vida das pessoas. }\end{array}$ \\
\hline Artemis & C & $\begin{array}{l}\text { Porque atualmente a Ciência é uma ferramenta que busca trazer bene- } \\
\text { fícios, comodidade, facilidades no dia a dia. }\end{array}$ \\
\hline Afrodite & B & $\begin{array}{l}\text { O homem é um ser vaidoso e essa vaidade o instiga na busca por con- } \\
\text { forto, para isso é necessário encontrar respostas para os fenômenos } \\
\text { que ocorrem no Universo, assim dentro de sua época, satisfazer os an- } \\
\text { seios sociais. }\end{array}$ \\
\hline Hera & A & $\begin{array}{l}\text { A Ciência, ou conhecimentos científicos, tem que ser comprovados atra- } \\
\text { vés de experimentos ou teorias. A escola atual é organizada por discipli- } \\
\text { nas e, cada disciplina trabalha o seu conhecimento específico científico. }\end{array}$ \\
\hline Héstia & C & $\begin{array}{l}\text { Acredito que a Ciência é um processo dinâmico, que deve estar em cons- } \\
\text { tante atualização e vinculado com os acontecimentos do dia a dia. }\end{array}$ \\
\hline Hermes & C & $\begin{array}{l}\text { A Ciência é um processo contínuo de descobertas, em que se procura } \\
\text { sempre buscar a resolução dos problemas enfrentados pela sociedade. }\end{array}$ \\
\hline
\end{tabular}

Fonte: Elaboração dos autores, 2019. 
Por meio da justificativa dos professores participantes é possível perceber que a maioria possui a compreensão da Ciência como uma atividade que busca por respostas, bem como sua relação com os interesses da sociedade. Vários professores apontam para as necessidades sociais como sendo algo a ser solucionado pela Ciência.

A professora Atena aborda, em sua fala, uma questão que desperta atenção no enfoque de transmissor do ensino de Ciências na formação de professores, segundo a exposição da mesma ao ser indagada sobre o que é Ciência: "É a Química. Sabe que eu nem me lembro de ter visto o conceito de Ciência. Acho que é algo que ajuda o ser humano, que estuda fenômenos na natureza, promove descobertas".

Dito isso, se percebe na fala da professora uma perspectiva que se aproxima de uma visão ahistórica e analítica, em que se pensa que a Ciência é o estudo da Química, não sendo considerado nesse trecho a associação com outras áreas, nem a construção do conhecimento científico ao longo dos anos.

O instrumento respondido pela professora Deméter tem consonância com uma das passagens de sua entrevista, em que ela narra a definição de Ciência: "Ciência para mim é a pesquisa, porque a gente vê na reportagem que cientistas estão descobrindo, então eu já tenho as ideias que é um grupo que tá pesquisando a solução de alguma coisa. Esse é meu conceito de Ciência".

A professora apresenta uma concepção que se distancia de uma visão individualista, pois a mesma associa o desenvolvimento científico a um grupo, bem como se afasta também da visão aproblemática, pois narra a expressão pesquisando $a$ solução de alguma coisa, pois ao tentar solucionar algo se tem uma pergunta de pesquisa subjacente.

A professora Hera apesar de trazer uma visão descontextualizada de Ciências no questionário, em sua fala na entrevista demonstra uma definição mais ampla de Ciência, segundo exposição a seguir:

Ciência para mim estão conhecimentos foram ao longo do tempo testados e comprovados através de modelos né. Teorias que servem para melhorar né, a vida do homem dando como exemplo a questão da descoberta dos medicamentos que curou muitas pessoas né. A anestesia, então a ciência a meu ver ela está a serviço do homem se bem dosado porque se ela for mal empregada a gente tem o caso das bombas, das substâncias, os agrotóxicos usados em excesso que podem matar contaminar o meio ambiente né, de uma forma geral matar animais. Então tem que ter uma um equilíbrio entre a ciência e seu uso sustentável. 
É possível identificar uma visão cumulativa de crescimento linear, pois indica a construção do conhecimento científico como algo gradual, em função da recorrência de termos que remetem à construção ao longo do tempo, desconsiderando os episódios de reformulação de teorias e as mudanças de paradigmas que ocorrem na construção do conhecimento científico. Verificam-se, também, traços que se aproximam de uma visão descontextualizada, que segue uma tendência simplista de que a Ciência e a tecnologia são culpadas pelas degradações no Planeta, sem levar em consideração que não são somente os cientistas que fomentam a degradação, isso ocorre em conjunto com a sociedade, de forma geral, impulsionada pelo consumo exacerbado, vinculado com diversos outros fatores.

Em relação à concepção de Ciência expressa pelo professor Hermes, o mesmo completa na entrevista um olhar interessante sobre a ideia de Ciência, abordando que:

[...] Ciência é a construção do conhecimento ao longo do tempo, a partir de algumas concepções e a partir da conquista ou do avanço tecnológico de algumas áreas, principalmente a química e a física. O objetivo principal isso aí, avanço tecnológico, fazer com que a ciência seja utilizada para o bem comum, e esse avanço vai ser utilizado cada vez mais, para facilitar a vida das pessoas.

O professor apresentou uma visão na qual o avanço tecnológico antecede 0 científico, se opondo a uma visão descontextualizada, porém apresenta uma visão cumulativa e de crescimento linear ao se remeter a Ciência como uma construção ao longo do tempo.

Em relação à segunda pergunta do questionário se buscou identificar a ideia dos professores sobre o que é ser um cientista. Nessa questão, os professores escreveram de forma aberta sua compreensão sobre a questão. As respostas se encontram descritas a seguir no Quadro 2. 
Quadro 2: Respostas dos professores na questão 2

\begin{tabular}{|l|l|}
\hline Professores & \multicolumn{1}{c|}{ Respostas } \\
\hline Atena & $\begin{array}{l}\text { Alguém que busca compreender fenômenos, desenvolve novas tecnologias ou pro- } \\
\text { põe inovações em qualquer área. }\end{array}$ \\
\hline Deméter & Um pesquisador. Alguém que vê um problema e se propõe a investigar e solucionar. \\
\hline Artemis & $\begin{array}{l}\text { É fazer descobertas que possam ser úteis à civilização. Não só no meio científico, } \\
\text { mas que traga benefícios no cotidiano, equipamento que nos facilitem o dia. }\end{array}$ \\
\hline Afrodite & $\begin{array}{l}\text { É um pesquisador que procura explicações no sentido da evolução e preservação } \\
\text { das espécies e planeta, assim como busca desenvolver novos tipos de materiais que } \\
\text { tornem possível esses processos. }\end{array}$ \\
\hline Hera & $\begin{array}{l}\text { Para mim um cientista é um pesquisador que se dedica por muito tempo em prol de } \\
\text { novos descobrimentos ou aprimoramento de descobertas para comprovar teorias ou } \\
\text { ações, substâncias para melhorar a vida em sociedade ou para adventos científicos } \\
\text { para a ciência, inovação e tecnologia. }\end{array}$ \\
\hline Héstia & $\begin{array}{l}\text { Estar em constante busca de aprendizado, trazendo novos questionamentos e bus- } \\
\text { cando a aplicação dos conhecimentos junto à sociedade. }\end{array}$ \\
\hline Hermes & $\begin{array}{l}\text { É estar sempre em busca de descobertas de meios ou métodos que possam resolver } \\
\text { os problemas da sociedade e tornar a vida das pessoas mais fácil. }\end{array}$ \\
\hline
\end{tabular}

Fonte: Elaboração dos autores, 2019.

Nesta questão é possível perceber as diferentes concepções dos professores em relação sobre o que é ser um cientista. A professora Artemis possui uma visão descontextualizada, ao narrar sobre o papel dos cientistas na produção de equipamentos, sem levar em consideração o trabalho dos técnicos na evolução da Ciência. As professoras Hera e Héstia possuem uma visão que se opõe à visão descontextualizada, pois trazem em suas falas os termos aprimoramento de descobertas e novos questionamentos, apontando para necessidade de questionar os conhecimentos já existentes, também articulando com a visão CTS ao relacionar Ciência, Tecnologia e Inovação juntamente com o melhoramento da vida em sociedade.

Segundo as concepções de Atena, o cientista é visto como alguém que desenvolve novas tecnologias e promove inovações, o que demonstra uma visão que se assemelha à perspectiva descontextualizada sobre o papel do cientista, demonstrando o pensamento arraigado que se tem de que os avanços tecnológicos são decorrentes das contribuições da Ciência, sem levar em consideração o papel dos técnicos.

$\mathrm{Na}$ terceira questão foi solicitado dos professores participantes que esses citassem o nome de dois cientistas que conhecem e indicassem o modo como cada um 
deles contribuiu para o avanço científico. As respostas fornecidas pelos professores se encontram expressas no Quadro 3, a seguir.

Quadro 3: Respostas dos professores na questão 3

\begin{tabular}{|c|c|c|}
\hline Professor & Cientista 1 & Cientista 2 \\
\hline Atena & $\begin{array}{l}\text { André Geim - Descoberta do grafeno } \\
\text { revolucionou a indústria de nanotecno- } \\
\text { logia, uma forma alotrópica de carbono } \\
\text { mais condutora que o silício. }\end{array}$ & $\begin{array}{l}\text { Lavoisier - Lei da conservação da massa. } \\
\text { "No mundo nada se cria, nada se perde, } \\
\text { tudo se transforma". }\end{array}$ \\
\hline Deméter & Antonie Lavoisier & Erwin Schrodinger \\
\hline Artemis & $\begin{array}{l}\text { Wholer - Síntese da ureia. Propôs com } \\
\text { esta descoberta a produção de produ- } \\
\text { tos artificiais que trouxeram benefícios } \\
\text { à humanidade. }\end{array}$ & $\begin{array}{l}\text { André Martins (Professor Doutor da UFS- } \\
\text { CAR) - Desenvolvimento de pele artificial } \\
\text { para peles com queimadura. Grande desco- } \\
\text { berta para humanidade. }\end{array}$ \\
\hline Afrodite & James Lovelock- Hipótese de Gaia & Stephen Hawking (Físico) - Teoria do cosmos. \\
\hline Hera & $\begin{array}{l}\text { Rutherford - Modelos atômicos } \\
\text { Newton - Leis da Física }\end{array}$ & $\begin{array}{l}\text { Wholer - Síntese da ureia ( } 1^{\circ} \text { composto or- } \\
\text { gânico produzido em laboratório). }\end{array}$ \\
\hline Héstia & $\begin{array}{l}\text { Vanderlan Bolzani - Reconhecido inter- } \\
\text { nacionalmente pelo trabalho desenvol- } \\
\text { vido em química orgânica de produtos } \\
\text { naturais e junto aos órgãos de fomento. }\end{array}$ & $\begin{array}{l}\text { Irene Mello - Pelo uso da tecnologia no en- } \\
\text { sino químico. Desenvolve uma imensurá- } \\
\text { vel contribuição para o processo de ensino } \\
\text { aprendizagem, especialmente, ensino de } \\
\text { química. }\end{array}$ \\
\hline Hermes & Não respondeu. & Não respondeu. \\
\hline
\end{tabular}

Fonte: Elaboração dos autores, 2019.

Nas respostas dos professores é possível perceber que a maioria citou nomes de antigos cientistas, que contribuíram para a evolução da Ciência de alguma forma. Apenas uma professora citou o nome de mulheres cientistas, o que pode indicar uma visão masculinizada da atividade científica, que está ligada com a visão destorcida individualista e elitista.

As professoras Artemis, Afrodite e Héstia citaram cientistas atuais, que se encontram desenvolvendo pesquisas no ramo da Ciência, demonstrando que as mesmas realizam leituras e estão a par das contribuições relativas à Ciência. A professora Héstia citou nome de uma pesquisadora na área de Educação, o que pode indicar certa oposição à visão exclusivamente analítica, já que são considerados apenas os pesquisadores que realizam estudos em laboratórios, tendo conhecimento de que a área da Educação e Ensino também contribui para o avanço científico. 
Na quarta questão foram apresentadas duas figuras, e foi solicitado aos professores que escolhessem entre essas a que melhor representasse o que eles consideram como atividade científica, e justificassem a escolha. As figuras apresentadas no questionário foram as figuras 1 e 2 apresentadas abaixo.

Figura 1: Cientista trabalhando

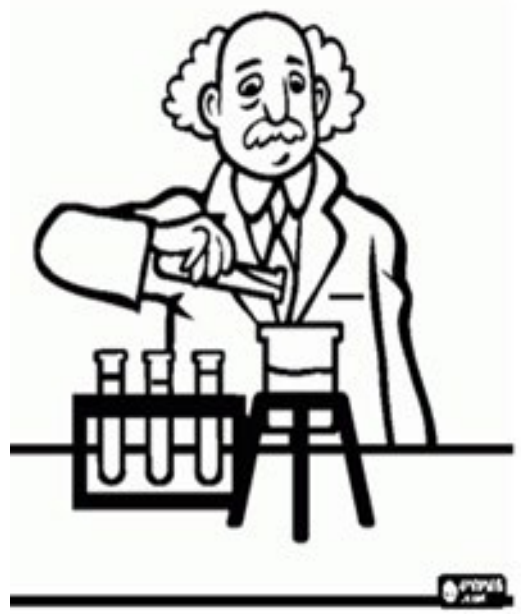

Fonte: Autor Desconhecido.
Figura 2: Cientista trabalhando

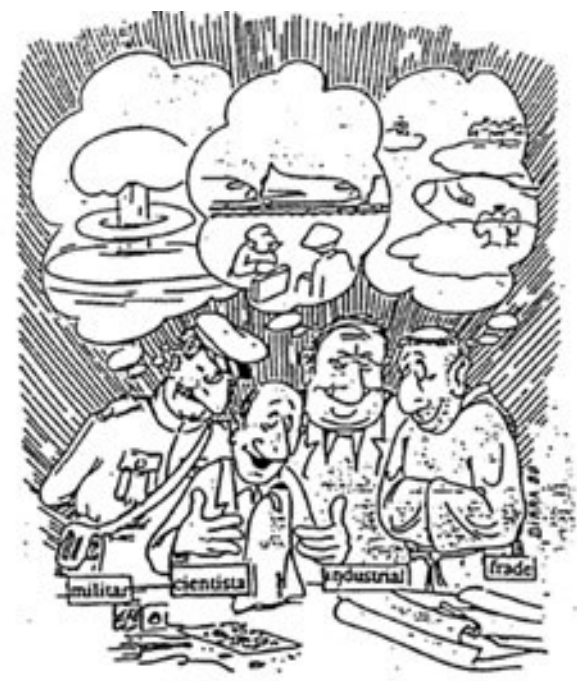

Fonte: Autor Desconhecido.

Na figura A se apresenta um cientista, que trabalha sozinho em um laboratório e, na figura 2, o cientista se encontra cercado de pessoas de diferentes áreas, discutindo questões sociais. Nessas imagens é possível destacar algumas visões deformadas de Ciência, que foram descritas por Cachapuz et al. (2005). Na figura 1 se tem ainda uma visão descontextualizada, aproblemática e empirista-indutivista da Ciência, porque não há representação de relação com a sociedade, não indica investigação de problemas e reduz a atividade científica ao processo de experimentação. Já a figura 2, mesmo tendo algumas distorções, representa mais claramente uma relação da atividade científica com as necessidades sociais.

Vale ressaltar que as imagens utilizadas serviram apenas como um meio de identificar a opinião geral dos professores. As imagens têm limitações, uma vez que apresentam visões exageradas em um único aspecto da atividade científica, em detrimento de outros. As escolhas e justificativas dos professores estão expressas no Quadro 4. 
Quadro 4: Respostas dos professores para a questão 4

\begin{tabular}{|c|c|c|}
\hline Professor & $\begin{array}{l}\text { Figura } \\
\text { Escolhida }\end{array}$ & Justificativa \\
\hline Atena & 2 & Todos juntos pela ciência, se tivessem o mesmo foco seria perfeito. \\
\hline Deméter & 2 & Estão discutindo para solução de algo. \\
\hline Artemis & 1 e 2 & $\begin{array}{l}\text { Considerando um cientista de laboratório A. Se for um cientista ou grupo } \\
\text { social científico a B. }\end{array}$ \\
\hline Afrodite & 2 & $\begin{array}{l}\text { A Ciência busca atender à sociedade de maneira geral, em todos os } \\
\text { segmentos e precisa do apoio de cada um deles. }\end{array}$ \\
\hline Hera & 1 & $\begin{array}{l}\text { A imagem demonstra um cientista com jaleco e trabalhando no laborató- } \\
\text { rio com tubos de ensaio, Becker e um tripé, possivelmente está fazendo } \\
\text { uma reação química. }\end{array}$ \\
\hline Héstia & 2 & Demonstra a necessidade de interação entre diversos profissionais. \\
\hline Hermes & 1 & $\begin{array}{l}\text { O cientista busca novas descobertas em nome do bem comum da socie- } \\
\text { dade, essa deveria ser a realidade. }\end{array}$ \\
\hline
\end{tabular}

Fonte: Elaboração dos autores, 2019.

Pode-se perceber que os professores Atena, Deméter, Afrodite e Héstia apresentaram uma visão conjunta em relação à atividade científica, indicando a figura 2 e suas justificativas, e se pode perceber com isso que está clara a necessidade da relação CTS, pois em suas justificativas demonstram a importância do trabalho em conjunto.

A professora Artemis demonstra uma transição de concepções, pois apresenta inicialmente uma visão individualista e, depois, relaciona o trabalho científico a um grupo social. Em relação à concepção apresentada pela professora Hera, essa mostra em sua justificativa uma concepção, que se alia com a visão individualista e elitista, pois enxerga o cientista como apenas os pesquisadores, que realizam estudos em laboratórios, não levando em consideração nesta questão o trabalho conjunto.

O professor Hermes escolheu a figura 1, porém em sua justificativa associou o trabalho de um cientista ao bem comum de uma sociedade, demonstrando uma disparidade, pois para a Ciência refletir no bem comum da sociedade, esta deve ter associação com outras áreas do conhecimento.

A quinta questão solicitava aos professores que respondessem se acreditavam ter possibilidade de se tornarem cientista, tendo que justificar o motivo. As respostas apresentadas à questão cinco estão expressas no Quadro 5: 
Quadro 5: Respostas dos professores à questão 5

\begin{tabular}{|c|c|c|}
\hline Professor & Resposta & Justificativa \\
\hline Atena & Sim & $\begin{array}{l}\text { Gostaria de desenvolver metodologias para o ensino de Química, onde } \\
\text { os alunos percebam que a Química faz parte de suas vidas. O caminho } \\
\text { seria analisar os } 17 \text { anos que já percorri e propor novos caminhos, novas } \\
\text { metodologias. }\end{array}$ \\
\hline Deméter & Sim & $\begin{array}{l}\text { Na educação, na busca por melhorias na qualidade do ensino. Para isso, } \\
\text { devo me qualificar nos estudos, me aprofundando no assunto. }\end{array}$ \\
\hline Artemis & Não & Deveria reintegrar a uma equipe de pesquisa. \\
\hline Afrodite & Sim & $\begin{array}{l}\text { Acredito que com } 32 \text { anos de profissão e as experiências vivenciadas, em } \\
\text { sala de aula, naturalmente ofereceram condições para na área de ensino. } \\
\text { Para efetivar isso em forma de registro os caminhos a serem seguidos } \\
\text { precisariam de tempo disponível (o que normalmente) não consigo esta- } \\
\text { belecer em minha rotina. }\end{array}$ \\
\hline Hera & Sim & $\begin{array}{l}\text { Através de experimentos químicos com materiais do dia a dia do aluno } \\
\text { para complementar a teoria. Neste caso é mais interessante que a unidade } \\
\text { escolar disponha de um laboratório de ciências em caso contrário é possí- } \\
\text { vel executar algumas práticas em sala de aula. }\end{array}$ \\
\hline Héstia & Sim & $\begin{array}{l}\text { O professor precisa buscar e pesquisar constantemente, pois cada aula pode } \\
\text { ser diferenciada e, acima de tudo, estar preparada para situações inusitadas. }\end{array}$ \\
\hline Hermes & Sim & Buscar cursos de pós-graduação que possam me elevar a esse patamar. \\
\hline
\end{tabular}

Fonte: Elaboração dos autores, 2019.

Para obter uma maior amplitude de informações, perguntou-se na entrevista se o(a) professor(a) se considerava um(a) cientista e, caso contrário, se ele teria a possibilidade de se tornar um(a). A professora Atena ao ser questionada, na entrevista, se a mesma se considerava uma cientista objetou que:

Não me considero uma cientista. Eu já pensei em ir no campo de pesquisadora né, que talvez é o início de uma pessoa se transformando cientista, mas aí eu interrompi e continuei professora. Eu não considero o professor um cientista embora ele descubra mil e uma maneiras didáticas de ensinar uma turma, mas ele não é um cientista, porque ele acaba só estudando os conceitos e passando, ele não vai atrás de uma nova descoberta, não no campo da Ciência, no campo da educação, mas se a educação estiver dentro da ciência, quem sabe né.

A professora demonstrou incoerência em suas respostas, pois o questionário aponta que tem possibilidade de se tornar uma cientista voltada para questões do ensino, e na entrevista não considera o professor um cientista.

Ao indagar a professora Deméter na entrevista sobre ser considerada uma cientista, a mesma respondeu: 
Não sou, porque não estou buscando muito a solução para algum tipo de problema, mas assim, em termos de como professora, a gente busca a questão do aprimoramento na sala de aula, da nossa aula, eu diria assim, não é um problema exatamente mas tenho vontade, já trabalhei na faculdade, no laboratório, achei muito interessante, fui aluna de iniciação científica, só que assim, como acabei indo para o rumo da sala de aula então agora eu estou mais em busca da questão da sala de aula mesmo, de aprimorar e tudo mais.

É evidente tanto nesta resposta, como nas anteriores, que a professora se afasta de uma visão aproblemática, pois é recorrente em sua fala a necessidade de se ter um problema subjacente à pesquisa. Apesar de a professora não possuir claramente a concepção de que um professor pode ser cientista, sendo professor pesquisador, como afirma Contreras (2002), a mesma demonstra interesse em se aprofundar em questões relativas ao ensino.

Em relação ao questionamento de ser vista como cientista, a professora Artemis redarguiu que:

Já foi uma né. Assim, porque para você ser um cientista só teórico até dá né, mas eu não me considero. Eu já fui né. A não ser que eu me vejo, assim como na parte de investigação de Educação, de observar meu aluno, de querer transformá-lo, eu posso até me considerar uma cientista nesse sentido aí, mas cientista de nível técnico, de laboratório de uma coisa assim, aí já não. Fiz Química, fiz mestrado, já trabalhei em laboratório, e tal, nesse sentido assim, mas não fui cientista da forma de ciência, pesquisa, tecnologia de ponta, aí não.

As concepções expressas pela professora Artemis demonstram que a mesma possui uma visão empírico-indutivista, pois centra a visão do cientista como aquele que está em laboratório replicando o método científico.

Ao indagar a professora Afrodite na entrevista sobre ser considerada uma cientista, a mesma obtemperou:

Eu acho que depois de tantos anos de sala de aula, a gente se torna um cientista, mas um cientista mais social do que voltado para área química, porque a idade do professor aumenta ao longo da tua vida, mas a idade do teu aluno ela permanece a mesma, porque você vê, eu dou aula para o Ensino Médio há mais de 30 anos, então a minha idade cronológica ela está aumentando, esse ano eu faço 60 anos então entre aspas, antes dos 30 eu já dava aula para alunos de Ensino Médio, que tem uma faixa de 13 a 18 anos em média e isso continuou, então hoje o que é que eu me torno um cientista social, porque essa relação ela se mantém mas ao mesmo tempo o aluno de hoje não é igual a um aluno de ontem.

Assim, a professora Afrodite apresenta uma concepção de cientista que se aproxima do enfoque social, se percebendo como agente de transformação em uma sociedade e se enxerga como professora pesquisadora. 
A professora Hera ao ser questionada na entrevista se poderia ser considerada uma cientista rebateu que:

Sim, na medida do possível eu tento buscar conhecimentos, participar de eventos, mas a gente sabe que a nossa realidade isso nem sempre é possível, porque nós não temos uma política que fomente a participação do professor fora das unidades escolar sem que tenha que deixar alguém no seu lugar, muitas vezes o próprio professor tem que bancar essa pessoa que vai ficar no seu no seu lugar, tem que bancar a sua participação em eventos através de passagens aéreas hospedagem e alimentação, então acaba que isso desmotivam os professores [...].

No questionário, a professora Hera apresentou uma visão que se associa com a ideia empírico-indutivista e ateórica de cientista, pois em sua concepção fazer Ciência estaria atrelado a desenvolver experimento em laboratório, também não relaciona a atividade científica a um problema de pesquisa.

A professora Héstia ao ser questionada na entrevista se poderia ser considerada uma cientista obtemperou que: "Sim né, pela própria formação, eu acho que a gente vem aí de um processo de pesquisa grande, isso nos faz já direto".

Por fim, o professor Hermes respondeu que:

Bom, de certa forma quando você trabalha com ciência, você trabalha com química e física você é um cientista né. A partir do momento que você mostra para os alunos, você faz uma aula prática você faz relação com ele teoria e prática você é um cientista.

Na sexta questão do questionário foi indagado aos professores se eles têm assistido a programas de TV e/ou realizado leituras sobre Ciência e suas aplicações. Em caso afirmativo, eles deveriam citar um programa e/ou revista. O objetivo desta questão era verificar se os professores estavam a par das contribuições científicas atuais. As respostas fornecidas pelos professores foram elencadas no Quadro 6 abaixo.

Quadro 6: Respostas dos professores para questão 6

\begin{tabular}{|l|l|l|}
\hline \multicolumn{1}{|c|}{ Professores } & \multicolumn{1}{|c|}{ Resposta } & \multicolumn{1}{c|}{ Programas e/ou revistas } \\
\hline Atena & Não & \\
\hline Deméter & Sim & Superinteressante, Química Nova \\
\hline Artemis & Sim & Química Nova \\
\hline Afrodite & Sim & Ciência Hoje, Galileu Galilei, Revistas Científicas nacionais \\
\hline Hera & Sim & Química Nova \\
\hline Héstia & Sim & Química Nova, Phytichemistry, National Geographic \\
\hline Hermes & Sim & \\
\hline
\end{tabular}

Fonte: Elaboração dos autores, 2019. 
Para garantir fidedignidade das informações foi perguntado novamente aos professores em entrevista se eles realizavam leituras ou acompanhavam programas sobre as Ciências e suas aplicações. A professora Atena ao ser indagada respondeu na entrevista: "Raramente, eu leio, mas assim texto de atualidades, mas que vem nos livros de uma escola particular que eu trabalho, que é um material que é atualizado constantemente, aí fala né das novas descobertas e tal, é o que eu que eu leio mais".

A professora Deméter obtemperou:

Então, eu gosto de ler revista que traga alguma coisa interessante, tipo Superinteressante, que tem umas coisas curiosas, alguma coisa atual, tipo, alguém descobriu alguma coisa, lá a gente dá uma lida para tentar aplicar em sala de aula. Programa de TV normalmente assisto alguns documentários, mas às vezes não tem muita relação com a química em si, que a maioria é documento histórico e tal, mas é interessante também, mas assim, é mais coisa voltada para educação mesmo, mais artigo essas coisas.

A professora Artemis proferiu:

Eu procuro sim, eu procuro essas revistas de ciências né, Galileu, a própria da química mesmo, da minha área do mestrado de vez em quando, apesar de estar afastada e tal, não está mais assim na área, mas eu estou sempre lendo alguma coisa e sempre que tem algo que eu possa comentar com os alunos em sala é bem interessante trazer uma curiosidade para eles que não tem essa percepção. Então os journals da vida, os American Scientist, enfim né. Galileu eu gosto muito, a Superinteressante que é mais para o Ensino Médio, eles também leem.

A professora Afrodite narrou na entrevista:

Principalmente na internet né, os tempinhos que a gente tem eu tenho acesso a Uol ciência, a Superinteressante, a Química Nova, então sim, a gente sempre tem olhado isso, até porque hoje não tem como você dar aula se você não buscar um pouco de atualização. $O$ aluno ele é muito mais atualizado do que o próprio professor, o aluno ele busca a internet constantemente, o professor já é um profissional e às vezes não tem tanto tempo quanto o aluno tem de trabalhar esse lado, então assim o que dá para ser feito precisa ser feito, para você não cair no caminho que que fica desatualizado totalmente [...].

A professora Hera respondeu: "Sim, nós temos são as tecnologias isso melhorou bastante porque o professor em qualquer lugar e tendo internet ele pode estar buscando revistas reportagens que possam estar auxiliando ele melhorar sua prática”.

A professora Héstia narrou em entrevista que:

Sim, constantemente, principalmente via internet, internet está aí e a gente tem essas facilidades. Antigamente você tinha que sentar na biblioteca, mas hoje você consegue trabalhar na internet bem mais tranquilamente. Costumo ver muito Nacional Geographic, Revista Phitochemistry eu leio muito ainda né. Aí depende, não existe uma específica porque eu busco mais os temas e vou trabalhando em cima deles. 
O professor Hermes respondeu:

Eu gosto muito da Química Nova, então é uma revista por exemplo eu utilizo não cotidianamente, não dá para fazer isso cotidianamente, porque do tempo, mas eu gosto de utilizar é um meio de comunicação que eu utilizo bastante, às vezes até para planejar minhas aulas minhas aulas práticas.

A maioria dos professores citou a revista da Química Nova, revista que traz importantes contribuições em relação aos resultados originais de pesquisa, artigo de revisão e educação, bem como Superinteressante e Galileu, que abordam curiosidades científicas e que possuem popularidade entre os alunos. As professoras Héstia e Artemis informaram, ainda, buscarem leituras de revistas referentes aos cursos de doutorado e mestrado que fizeram.

Com base na análise das repostas dos professores, nas seis questões, observou-se de forma geral que as visões de deformações mais recorrentes presentes no discurso dos mesmos são: 1) uma visão descontextualizada; 2) uma concepção individualista e elitista e 7) uma visão cumulativa, de crescimento linear, sendo que cada uma dessas deformações aparecem duas vezes no discurso dos professores. As visões 3) uma concepção empiro-indutivista e ateórica e 5) uma visão aproblemática e ahistórica aparecem uma vez.

\section{Considerações finais}

De forma geral, foi possível observar que existem diferentes concepções de Ciência no discurso dos professores, podendo afirmar que não persiste uma concepção predominante, que transponha o pensamento dos professores. As visões deformadas apresentadas pelos professores e presentes na literatura são decorrentes de longos anos de um trabalho com caráter reprodutor alicerçado no modelo epistemológico positivista, que consiste na aplicação do método científico em questões do ensino. Todavia, em se tratando do ensino de Ciência/Química, é normal existir um choque de concepções, pois se trata de um estudo da natureza matematizável, e que ao mesmo tempo está atrelado com processos constantes de tomada de consciência, pois se trata de uma Ciência dinâmica em constante atualização e passível de mudanças de paradigmas. Por isso, a importância que os professores aprofundem seus conhecimentos em questões associadas ao Ensino de Ciência, dissociando de noções deformadas a respeito da construção do conhecimento científico. 
Em síntese, todas as situações que não podem ser solucionadas a partir de um roteiro quantitativo, e que compreendem dimensões humanas de consciência e de reflexão, estas não são analisadas no modelo positivista. Assim, essa visão pautada na racionalidade técnica não consegue dar conta de explicar as profissões que lidam com o outro, na qual segundo Tardif e Lessard (2005, p. 20): "baseiam-se em conceitos complexos (necessidade, personalidade, desenvolvimento de si, saúde, autonomia, etc.) que traduzem a complexidade das próprias situações de trabalho que eles precisam assumir junto às pessoas”. Dessa forma, as práticas profissionais são permeadas de relações de interrogações, que não podem ser avaliadas com uso de roteiros e técnicas simples.

Sendo assim, é compreensível que certos professores apresentem visões deformadas da Ciência, pois o professor representa a sociedade em que está inserido e na conjectura atual se está vivendo uma geração de transição perante questões do Ensino, que perduram de longos anos pautados na racionalidade técnica, que compõe o paradigma alicerçador da Filosofia e da Ciência Moderna promovida a partir do século XVI e que hoje não consegue dar conta de explicar as profissões que lidam com o outro, e nem compreender a base epistemológica subjancente a sua prática pedagógica ao ensinar qualquer componente curricular da área das Ciências da Natureza.

Por outro lado, tal realidade expressa nas respostas dos sujeitos pode ser ressignificada, tendo em vista que a formação de um professor compreende uma relação de constante movimento que nunca cessa. Com isso, evidencia-se a primordialidade da formação continuada, colocando o professor no centro do processo, de forma intencional no decurso, para que necessidades formativas possam ser ressignificadas, acarretando assim em uma metamorfose metodológica, no incessante processo de reflexão que é inerente à profissão de professor.

Por fim, as reflexões obtidas por meio desta pesquisa contribuíram para a construção de um produto educacional em formato de fascículo com a intenção de subsidiar a formação continuada para professores em atuação, em busca de auxiliar em suas possíveis necessidades formativas no ensino de Ciências Naturais. 


\section{Epistemological views on the practice of chemistry teachers}

\section{Abstract}

This article is a section of a master's research conducted with supervising professors of the Institutional Teaching Initiation Scholarship Program (PIBID) and Pedagogical Residency (PRP) of the Degree in Chemistry of a public university in the state of Mato Grosso, Brazil. Thus, the guiding question was based on the following terms: How are the conceptions of Science and didactic models that underlie the pedagogical practices of Chemistry teachers in action, when reporting the Chemistry Teaching they perform in Education? Basic? This paper seeks to contextualize the relations between subject-object and the construction of scientific knowledge over time, calling for the importance of teachers to know about the epistemological bases that support the scientific pedagogical work. Also from the perspective of the teacher, who analyzes his practice, brings the relevance of scientific education in society and the importance of understanding it. The methodology is based on the contribution of qualitative research, using the case study approach, and sought through questionnaires containing open questions, and semi-structured interview to verify possible formative needs regarding the conceptions of Science expressed by teachers based on the seven views deformities present in the literature. The method of analysis and construction of the research texts was through discursive textual analysis (ATD). The results indicate a need for teachers to reflect on the science they are teaching in order to ensure an integrative and more meaningful teaching of scientific concepts. The reflections of this survey contributed to the construction of an educational product in fascicle format with the intention of subsidizing the continuing education for acting teachers, seeking to assist in their possible formative needs in Science Education.

Keywords: Science Education; Epistemology; Science teaching; Teacher formation.

\section{Notas}

1 Este artigo abordará apenas as concepções de Ciência no discurso dos participantes da pesquisa.

2 A proposta de formação no formato de fascículo poderá ser acessada no seguinte endereço eletrônico: http:// fisica.ufmt.br/pgecn/index.php/dissertacoes-e-produtos-educacionais/banco-de-produtos-educacionais/search_result?search_phrase=andreza\&catid=0\&ordering=newest\&search_mode=any\&search_where\%5B\%$5 \mathrm{D}=$ search_name\&search_where $\% 5 \mathrm{~B} \% 5 \mathrm{D}=$ search_description

3 Corrente que prega que o ser já nasce com conhecimento e este não é adquirido pela experiência.

4 Palavra grega que dá o sentido de ideia.

5 Termo campo utilizado segundo as perspectivas do sociólogo Pierre Bourdieu. Compreende relações de poder e envolve múltiplos agentes, que podem ser instituições, indivíduos ou no caso educacional, as múltiplas identidades docentes que configuram o ensino.

${ }_{6}$ Periódico destinado para profissionais e pesquisadores na área de Educação científica, que aborda questões sobre ensino e aprendizagem de Ciências, Política e Educação Científica.

7 Termo utilizado por Shamos (1995) em seu livro The Myth of Scientific Literacy.

8 Esotérico: conhecimento acessível para poucos.

$9 \quad$ Faz-se a opção de não identificar a Universidade para resguardar a identidade de todos os envolvidos nesta pesquisa.

10 Os nomes fictícios, femininos e masculino, foram atribuídos aos professores participantes por escolha da pesquisadora, de modo a referenciar as deusas e deus da mitologia grega. 


\section{Referências}

BELLO, A. A. Introdução à fenomenologia. Bauru: Edusc, 2006. (Filosofia e política).

CACHAPUZ, A.; GIL-PEREZ, D; CARVALHO, A. M. P.; PRAIA, J.; VILCHES, A. A Necessária Renovação do Ensino de Ciências. São Paulo: Cortez, 2005.

CARVAlHO, A. M. P., GIL-PÉREZ, D. Formação de Professor de Ciências. 10. Ed. São Paulo: Cortez, 2011

CAVALCANTI, A.S. Olhares epistemológicos e a pesquisa educacional na formação de professores. Educação Pesquisa. São Paulo, v. 40, n. 4, 2014, p. 983-998.

CONTRERAS, J. Autonomia de professores. São Paulo: Cortez, 2002.

GAMBOA, S.S. Pesquisa em educação: métodos e epistemologias. 2. ed. Chapecó/SC: Argos, 2012.

GIL PÉREZ; D., MONTORO, I. F., ALÍS; J. C., CACHAPUZ, A. \& PRAIA; J. Por uma imagem não deformada do trabalho científico. Ciência \& Educação, v. 7, n. 2, p. 125-153, 2001.

MARCONDES, D. Iniciação à história da filosofia: dos pré-socráticos a Wittgenstein. 6. ed. Rio de Janeiro: J. Zahar, 2001.

MORAES, R; GALIAZZI, M. C. Análise Textual Discursiva. Ijuí: Ed. Unijuí, 2007.

MORIN, Edgar. Introdução ao pensamento complexo. Porto Alegre: Sulina, 2006.

PRAIA, J; CACHAPUZ, Antonio; GIL-PÉREZ, Daniel. Problema, teoria e observação em ciência: para uma reorientação epistemológica da educação em ciência. Ciência \& Educação, v. 8, n. 1, p. $127-145,2002$.

SCHNETZLER, R. P.; A pesquisa em Ensino de Química no Brasil: conquistas e perspectivas. Química Nova, v. 25, p. 14-35, jul.2002

TARDIF, M., LESSARD, C. O trabalho docente hoje: elementos para um quadro de análise. In: $O$ trabalho docente: elementos para uma teoria da docência como profissão de interações humanas. Petrópolis: Vozes, 2005.

TESSER, J. G. Principais linhas epistemológicas contemporâneas. Educ. ver, Curitiba, n. 10, p. 91-98, 1994.

YIN, R.K. Estudo de caso - planejamento e métodos. 2. ed. Porto Alegre: Bookman, 2001. 